\title{
MODAL INTELEKTUAL SEBAGAI SUMBER KEUNGGULAN BERSAING BERBASIS NILAI (CARBV) (STUDI PADA PROGRAM STUDI PERGURUAN TINGGI NEGERI DI BANDUNG JAWA BARAT)
}

\author{
Joeliaty \\ Fakultas Ekonomi Dan Bisnis, Universitas Padjadjaran \\ joeliaty@yahoo.co.id
}

\begin{abstract}
ABSTRAK
Salah satu lembaga pendidikan tinggi yang secara formal diserahi tugas dan tanggung jawab mempersiapkan mahasiswa sesuai dengan tujuan pendidikan nasional adalah Perguruan Tnggi Negeri. Program Studi adalah bentuk produk pendidikan yang ditawarkan di Perguruan Tinggi, karena itu program studilah yang menentukan mutu pendidikan. Kenyataannya mutu pendidikan program studi beragam. Karena itu setiap program studi harus berusaha mengelola programnya secara tepat guna mencapai keungulan bersaing.

Tujuan dari penelitian ini adalah untuk menghasilkan suatu kajian tentang modal intelektual sebagai sumber keunggulan bersaing program studi sarjana Perguruan Tinggi Negeri di Bandung.Penelitian ini dilakukan dengan metode deskriptif dan verifikatif, melalui survey yang melibatkan 55 sampel .Data diperoleh dari hasil observasi,penyebaran kuesioner dan wawancara. Analisis pengolahan datanya menggunakan Partial Least Square (PLS) dengan software Visual PLS dan XLStat.

Hasil penelitian menunjukkan bahwa pendayagunaan modal intelektual secara optimal tergantung dari sejauhmana program studi mampu mengelola modal relasinya.Aspek yang paling menentukan keunggulan bersaing adalah sumber daya manusia (human capital )yang memiliki keahlian,pengetahuan dan kemampuan untuk menjalankan tugas yang tidak sama (rare) dengan yang disediakan oleh pesaing. Hasil pengujian hipotesis menunjukkan bahwa modal intelektual berpengaruh signifikan terhadap keunggulan bersaing.Yang berarti bahwa modal intelektual dapat menjadi sumber keunggulan bersaing pada pogram studi.
\end{abstract}

Kata kunci: Modal Intelektual, Keunggulan Bersaing dan Program Studi

\section{Pendahuluan}

\section{Latar belakang}

Tujuan pendidikan nasional adalah mengisi kebutuhan masyarakat akan tersediannya tenaga ahli dan tenaga terampil dengan tingkat dan jenis kemampuan yang sangat beragam.Lembaga pendidikan yang secara formal diserahi tugas dan tanggung jawab mempersiapkan mahasiswa sesuai dengan tujuan pendidikan nasional adalah Perguruan Tinggi. Karena itu mahasiswa sebagai peserta didik dan generasi muda yang mempunyai kedudukan dan peranan penting dalam mewujudkan cita-cita pembangunan nasional, senantiasa perlu dibimbing dan dikembangkan. Produk pendidikan di perguruan tinggi ditawarkan dalam bentuk program studi, karena itu program studilah yang menentukan mutu pendidikan (Badan Akreditasi Nasional /BAN 2008), dan kenyataan bahwa mutu pendidikan program studi beragam. Mutu program studi akan tergambar dalam bentuk kurikulum yang ditawarkan pada mahasiswa, sehingga hasil lulusan program studi tersebut dapat diterima oleh pengguna (industri). Pada kenyataannya masih banyak lulusan yang tidak terserap oleh pengguna seperti yang dikatakan oleh Ono Suparno (Pikiran Rakyat, 4Maret 2010). Hal ini mengindikasikan bahwa kurikulum yang ditawarkan belum menggambarkan kebutuhan pengguna, atau dengan kata lain belum berdasarkan kompetensi (KKB).

Mengingat Undang-undang RI Nomor 20 Tahun 2003, PP RI Nomor 19 Tahun 2005 dan peraturan perundang-undangan lainnya serta kecenderungan perkembangan kebijakan tentang pendidikan 
tinggi yang menekankan pada mutu dan akuntabilitas publik institusi perguruan tinggi dan program studi maka diperlukan akreditasi program studi sarjana. Akreditasi dilakukan untuk menentukan kelayakan program dan satuan pendidikan pada jalur pendidikan formal dan nonformal setiap jenjang dan jenis pendidikan. (BAN PT Program Sarjana 2008).Dari beberapa Perguruan Tinggi di Kota Bandung terdapat tiga Perguruan Tinggi Negeri yang dapat berperan dalam meningkatkan mutu pendidikan, yaitu Universitas Padjadjaran (Unpad), Institut Teknologi Bandung (ITB) dan Universitas Pendidikan Indonesia (UPI). Tingkat Akreditasi program studi di tiga Perguruan Tinggi tersebut masih ada yang berperingkat B. Hal ini menunjukkan bahwa, kualitas pendidikannya masih belum sesuai dengan harapan, yang berarti pula kinerja program studi tersebut masih belum memenuhi standar yang telah ditetapkan.

Menurut hasil riset Smith dan Ennew (2000) dalam Prabowo (2005) ,menyatakan bahwa kualitas dan mutu akademik menunjukkan dampak pada word of mouth communications, yang berarti bahwa sumber daya atau unsur-unsur jasa mempunyai pengaruh terhadap keinginan mahasiswa untuk memberikan rekomendasi terhadap jasa program studi perguruan tinggi yang secara bersamaan membentuk citra program studi dan berdampak pada jumlah peminat calon mahasiswa di program studi tersebut. Demikian pula yang terjadi pada Perguruan Tinggi Negeri di Bandung, bahwa jasa layanan terhadap mahasiswa yang secara langsung dilakukan melalui program studi akan memberikan dampak pada jumlah peminat calon mahasiswa, dengan demikian citra dan jumlah peminat merupakan indikator terpenting dari tercapainya tujuan organisasi dan keunggulan bersaing program studi yang tercermin dari tingkat keketatan mahasiswa (rasio peminat dan diterima). Berdasarkan pengamatan bahwa selain peminatnya jauh melebihi tempat yang tersedia, juga menunjukkan bahwa rata-rata keketatan mahasiswa tahun terakhir menurun, hal ini disebabkan tingkat pendaftar dari jumlah yang diterima menurun. Untuk memperkuat reputasi dan citra tersebut, maka dibutuhkan, sumber daya manusia yang unggul (competitive advantage resource base value), memiliki kompetensi untuk mengelola program studi. Sejalan dengan pendapat dari Berger (2008) faktor yang paling berkontribusi dalam penciptaan dan pemeliharaan keunggulan organisasi adalah sumber daya manusia.Tingkat keunggulan sumber daya manusia program studi ,saat ini khususnya tenaga administrasi masih rendah, dikarenakan tingkat pendidikan formal yang belum memadai.

Ramirez (2007) mengemukakan bahwa sumber daya yang sangat bernilai dari universitas adalah tenaga pendidik (dosen), peneliti, tenaga kependidikan (tenaga administrasi) dan mahasiswa (human capital) dengan proses keorganisasian (structural capital) dan jaringan relasi mereka (relation capital). Sumber daya ini merupakan bagian dari intellectual capital, merupakan intangible assets bagi perguruan tinggi,sebagai sumber yang signifikan untuk mencapai keunggulan organisasi.Perguruan Tinggi sebagai penghasil pengetahuan,artinya terdiri dari komunitas yang berpengetahuan (modal inelektual) mempunyai kemampuan belajar ,daya inovasi, dan sebagai input yang diproses melalui manajemen pengetahuan (Bueno dalam Ramirez,2007). Berdasarkan fenomena di atas, maka perlu dikaji melalui penelitian, dengan judul "Modal Intelektual Sebagai Sumber Keunggulan Bersaing (Kajian Pada Program Studi Perguruan Tinggi Negeri Di Bandung).

\section{Tujuan penelitian}

Adapun tujuan dari penelitian ini adalah untuk menganalisis dan menghasilkan kajian tentang modal intelektual yang menentukan tercapainya keunggulan bersaing program studi Perguruan Tinggi Negeri di Bandung. Sedangkan manfaat hasil penelitian ini diharapkan dapat menjadi sumbangan pengembangan ilmu pengetahuan dalam bidang ilmu strategi manajemen sumber daya manusia, 
terutama mengenai modal intelektual (intellectual capital), dan keunggulan bersaing (competitve advantage).Serta diharapkan menjadi sumbangan pemikiran kepada pihak Universitas Negeri yang ada di Bandung khususnya bagi Program Studi binaan Unpad, ITB, dan UPI sebagai pengambilan keputusan terkait dengan peningkatan kualitas program studi sarjana untuk masing-masing fakultas, baik kualitas tenaga pendidik (Dosen), mahasiswa maupun tenaga kependidikan (Tenaga Administrasi).

\section{METODE PENELITIAN}

Pengamatan dilakukan terhadap pengelola, dosen dan mahasiswa program studi sarjana Perguruan Tinggi Negeri (PTN) di Bandung (Unpad, ITB dan UPI). Sesuai dengan tujuan penelitian yang ingin dicapai, maka digunakan dua jenis /bentuk penelitian, yaitu penelitian deskriptif dan penelitian verifikatif. Penelitian deskriptif dilakukan dengan tujuan untuk mendapatkan deskripsi tentang cirriciri variable penelitian (modal intelektual, dan keunggulan bersaing program studi), sedangkan penelitian verifikatif dilakukan dengan tujuan untuk mengetahui pengujian data variable yang diteliti.

Jumlah sampel yang dapat diteliti sebanyak 55 program studi, sebagai unit analisis.Sedangkan unit observasi sebanyak 330 orang responden. Untuk jelasnya berikut Tabel 1. Jumlah responden untuk setiap unit analysis Sampel Program Studi Sarjana yang terakreditasi sbb:

Tabel 1. Jumlah responden setiap unit analysis dan nilai akreditasi sampel program studi sarjana perguruan tinggi negeri di Bandung

\begin{tabular}{lccccccccc}
\hline & & \multicolumn{9}{c}{ Unit Obsevasi } & & \multicolumn{2}{c}{ Akreditasi } \\
\cline { 3 - 9 } Universitas & Unit Analysis & & Kaprodi & Dosen & $\begin{array}{c}\text { Tenaga } \\
\text { Administrasi }\end{array}$ & Mahasiswa & & A & B \\
\cline { 3 - 10 } & & 17 & 34 & 17 & 34 & 102 & 13 & 4 \\
\hline UNPAD & 18 & 18 & 36 & 18 & 36 & 108 & 16 & 2 \\
\hline ITB & 20 & 20 & 40 & 20 & 40 & 120 & 14 & 6 \\
\hline UPI & $\mathbf{5 5}$ & $\mathbf{5 5}$ & $\mathbf{1 1 0}$ & $\mathbf{5 5}$ & $\mathbf{1 1 0}$ & $\mathbf{3 3 0}$ & $\mathbf{4 3}$ & $\mathbf{1 2}$ \\
\hline Total & & & & & & & &
\end{tabular}

Sumber:Populasi diolah (2010)

Teknik pengumpulan data yang digunakan melalui studi pustaka,observasi, kuesioner dan wawancara.Data primer diperoleh melalui penelitian lapangan, yang diperoleh dengan cara ; wawancara, sebagai teknik komunikasi langsung untuk memperoleh data-data yang diperlukan, khususnya dilakukan komunikasi dengan ketua/sekretaris, tenaga administrasi , dan dosen masingmasing program studi sarjana Perguruan Tinggi Negeri di Bandung, tentang modal intelektual. Sedangkan komunikasi dengan mahasiswa tentang keunggulan bersaing program studi. Data primer diperoleh dengan mengajukan berbagai pertanyaan melalui questioner, agar jawaban responden memenuhi kriteria atas pengukuran yang baik, maka sebelum daftar pertanyaan diserahkkan ke responden terlebih dahulu harus diuji reliabilitas dan Validitas (Cooper \& Schindler,2008).Data sekunder digunakan untuk menggambarkan keadaan umum dari objek yang diteliti berikut kondisinya, diperoleh dari instansi terkait, baik dri situs web maupun dari laporan tahunan tenaga kependidikan, serta melalui studi pustaka. 
Rancangan Analisis dalam penelitian ini adalah menggunakan dua analisis yaitu: (1)menggunakan analisis deskriptif , untuk mendeskripsikan masing-masing variable dalam penelitian ini, sehingga akan diperoleh informasi mengenai gambaran tentang tanggapan serta penilaian pengelola ,dosen dan mahasiswa program studi sarjana Perguruan Tinggi Negeri di Bandung terhadap variablevariabel penelitian .analaisis ini dilakukan secara menyeluruh dan juga berdasarkan masing-masing institusi sehingga bisa dilihat gambaran untuk masing-masing institusi ,dilakukan langkah-langkah sebagai berikut :

a) Setiap indikator variabel yang dinilai oleh responden, diklasifikasikan ke dalam tujuh alternatif jawaban dengan menggunakan semantik diferensial yang menggambarkan peringkat jawaban. Peringkat jawaban setiap indikator diberi skor antaral sampai dengan 7.

b) Dihitung total skor tiap indikator variabel = jumlah skor dari semua skor indikator variabel untuk semua responden.(Kaprodi,Dosen,Sub Bidang Akademik /SBA).

c) Dihitung skor tiap variabel /sub variabel = rata-rata dari total skor Perhitungan rata-rata setiap variabel memperhatikan kelompok responden. Untuk setiap variabel dan kelompok respoden dilakukan pembobotan .dengan bobot sebagai berikut:

d) Untuk mendeskripsikan jawaban responden juga digunakan statistik deskriptif seperti distribusi frekwensi dan ditampilkan dalam bentuk tabel ataupun diagram dengan menggunakan bantuan software Exell dan SPSS.

Selanjutnya setelah dilakukan analisis deskriptif, akan dilanjutkan ke analisis yang kedua analisis verivikatif, yaitu dengan menggunakan alat uji t.

\section{HASIL DAN PEMBAHASAN PENELITIAN}

\section{Kondisi modal intelektual program studi}

Semua program studi secara umum telah mendayagunakan secara optimal modal intelektualnya. Hasil peritungan memberikan rata-rata atau skor total untuk variabel modal intelektual program studi sebesar 5.5, termasuk dalam kategori tinggi. Artinya bahwa pendapat semua ,baik ketua program studi, dosen maupun tenaga administrasi , mengatakan bahwa telah mendayagunakan modal manusia secara optimal melalui perhatiannya terhadap peningkatan pengetahuan, kemampuan, keterampilan ,sikap maupun perilaku melalui pelatihan ,pendidikan dan pengembangan bagi civitas academi ,sehingga program studi telah memiliki pimpinan yang mempunyai kompetensi yang memadai untuk memimpin program studi, memiliki dosen yang mempunyai kualifikasi dapat mentransfer ilmu dalam ruang belajar kepada mahasiswa yang merupakan output dari perguruan tinggi negeri, serta didukung oleh tenaga administrasi yang memiliki pengalaman dan keahlian di bidangnya. Hal ini sejalan dengan pendapat Lukito (2009) bahwa adanya sumber daya manusia yang memiliki pengetahuan, gagasan, keahlian serta pengalaman untuk dapat membentuk sumber daya manusia yang superior yang menjadi aset penting bagi organisasi. Keempat unsur tersebut di atas merupakan modal yang tidak akan habis atau hilang begitu saja. Begitupula terhadap modal structural, program studi telah menjalankan fungsinya sesuai dengan prosedur /system yang telah ditetapkan. Sedangkan modal relasi masih agak kurang diperhatikan, artinya program studi belum maksimal dalam menjalin hubungan dengan instansi lain misalnya mengadakan kerjasama dalam bidang pengajaran, penelitian dan pengambdian pada masyarakat dengan program studi lain terutama program studi di luar negeri, serta memberi kesempatan pada dosen untuk menjadi anggota organisasi yang sesuai dengan bidang keilmuan. Hal 
ini akan mempengaruhi terhadap keungulan bersaing yang ingin dicapai dan dampaknya terhadap kinerja program studi, sejalan dengan pendapat dari Kianto et al (2010) bahwa modal intelektual adalah perangkat yang diperlukan untuk menemukan peluang dan mengelola ancaman dalam kehidupan.Begitupun pendapat dari Maalone (2010) bahwa modal intelektual perusahaan memiliki dampak positif pada kinerja organisasi.

Namun apakah hasil ini sebatas karena fenomena sampel ataukah bisa dilakukan pengambilan kesimpulan secara umum. Supaya hasil statistik dapat disimpulkan secara umum untuk populasi penelitian, maka perlu dilakukan pengujian hipotesis. Pada Bab dua telah dihipotesiskan bahwa program studi telah mendayagunakan modal intelektual secara efektif. Secara statistik, modal intelektual program studi dinyatakan memiliki kategori kuat, jika memiliki skor rata-rata lebih besar dari 5. Pengujian hipotesis dilakukan untuk membuktikan apakah secara general modal intelektual program studi berkategori tinggi. Pengujiannya dilakukan menggunakan uji rata-rata dengan uji satu pihak.

Hipotesis

H0: $\mu<5.1 \quad$ Modal intelektual program studi secara umum belum didayagunakan optimal

H1: $\mu \geq 5.1 \quad$ Modal intelektual program studi secara umum sudah didayagunakan optimal. Statistik uji yang digunakan adalah:

$$
t_{1}=\frac{\bar{X}_{1}-5}{s_{1} / \sqrt{n}}
$$

Dengan $\bar{X}_{1}$ adalah skor rata-rata dari variabel laten modal intelektual program studi. Selanjutnya $s$ menunjukkan nilai simpangan baku, dengan $\mathrm{n}$ adalah banyak unit analisis. Sedangkan angka lima menunjukan nilai parameter yang dihipotesiskan. Hasil perhitungan dengan MS. Excel diperloleh nilai $\bar{X}_{1}=5.50$ dengan simpangan baku 0.524 . Selanjutnya dengan ukuran sampel sebesar 55 dilakukan perhitungan nilai t hitung sebagai berikut:

$$
t_{1}=\frac{5.5-5.0}{0.524 / \sqrt{55}}=7.07
$$

Kriteria penerimaan dan penolakan hipotesis nol sebagai berikut:

- Tolak hipotesis nol jika nilai t hitung lebih besar dari nilai t tabel. Hasil perhitungan memberikan nilai sebesar 7.07. Nilai ini lebih besar dibandingkan dengan nilai t tabel pada tingkat signifikansi 5\% derajat sebesar 55 sebesar 2.01. Sehingga dari hasil pengujian ini dapat disimpulkan bahwa modal intelektual program studi secara umum sudah didayagunakan secara optimal.

\section{Kondisi keunggulan bersaing program studi}

Secara umum program studi memiliki kategori keunggulan bersaing yang unggul yaitu dinilai dengan skor rata-rata 5,7, yang tercermin dari tingkat sumber daya manusia program studi (pimpinan, dosen dan tenaga administrasi) memiliki tingkat pengendalian diri, empati dan bakat yang tinggi, serta memiliki tingkat nilai (valuable) yang tinggi pula. Selain itu memiliki kontribusi, dan kreatifitas yang jarang ditemukan serta memiliki pengetahuan dan kompetensi yang tidak dapat ditiru. Afiouni, (2007) mengatakan bahwa, pandangan yang berbasis sumber daya (Resource Based 
Value) menekankan bahwa sebuah organisasi menggunakan sumber daya dan kemampuan untuk menciptakan keunggulan kompetitif yang pada akhirnya menghasilkan penciptaan nilai unggul.

Begitu pula yang terjadi pada program studi dalam penelitian ini ,berdasarkan hasil pengolahan data bahwa pimpinan, dosen dan tenaga administrasi telah memiliki keunggulan yang tercermin dari proses pelayanan terhadap mahasiswa melayani dengan efektif, yang akan berdampak terhadap kinerja program studi, walaupun masih ada kekurangan dari tenaga administrasi dalam melayani mahasiswa agak kurang kreatif,kurang menunjukkan keandalan dalam memecahkan masalah pelayanan terhadap mahasiswa ,karena umumnya pendidikan tenaga administrasi rata-rata masih Sekolah Menengah Atas.Padahal kualitas dan mutu akademik menurut studi menunjukkan dampak pada word of mouth communications, artinya sumber daya atau unsur-unsur jasa mempunyai pengaruh terhadap keinginan mahasiswa untuk memberikan rekomendasi terhadap jasa institusi perguruan tinggi yang secara bersamaan membentuk citra institusi dan berdampak pada jumlah peminat calon mahasiswa di institusi tersebut (Prabowo,2005).

Namun apakah hasil ini sebatas karena fenomena sampel ataukah bisa dilakukan pengambilan kesimpulan secara umum. Supaya hasil statistik dapat disimpulkan secara umum untuk populasi penelitian, maka perlu dilakukan pengujian hipotesis. Pada bab dua telah dihipotesiskan bahwa tingkat keunggulan bersaing program studi sudah unggul. Secara statistik, keunggulan bersaing program studi dinyatakan tinggi jika memiliki skor rata-rata lebih besar dari 5. Pengujian hipotesis dilakukan untuk membuktikan apakah secara general keunggulan bersaing program studi sudah tinggi. Pengujiannya dilakukan menggunakan uji rata-rata dengan uji satu pihak.

Hipotesis

$\mathrm{H}_{0}: \mu<5.1 \quad$ Keunggulan bersaing program studi secara umum belum unggul

$\mathrm{H}_{1}: \mu \geq 5.1 \quad$ Keunggulan bersaing program studi secara umum sudah unggul

Statistik uji yang digunakan adalah:

$$
t_{3}=\frac{\overline{Y_{1}}-5}{s_{3} / \sqrt{n}} \ldots \ldots . .(2)
$$

Dengan $\bar{Y}_{1}$ adalah skor rata-rata dari variabel laten keunggulan bersaing program studi. Selanjutnya $s_{3}$ menunjukkan nilai simpangan baku, dengan $\mathrm{n}$ adalah banyak unit analisis. Sedangkan angka lima menunjukan nilai parameter yang dihipotesiskan.

Hasil perhitungan dengan MS. Excel diperloleh nilai $\bar{Y}_{1}=5.70$ dengan simpangan baku 0.543 . Selanjutnya dengan ukuran sampel sebesar 55 dilakukan perhitungan nilai t hitung sebagai berikut:

$$
t_{3}=\frac{5.7-5.0}{0.543 / \sqrt{55}}=9.57
$$

Kriteria penerimaan dan penolakan hipotesis nol sebagai berikut:

- Tolak hipotesis nol jika nilai t hitung lebih besar dari nilai t tabel.

Hasil perhitungan memberikan nilai sebesar 9.57. Nilai ini lebih besar dibandingkan dengan nilai $t$ tabel pada tingkat signifikansi 5\% derajat sebesar 54 sebesar 2.01. Sehingga dari hasil pengujian ini dapat disimpulkan bahwa keunggulan bersaing program studi secara umum sudah unggul. 


\section{Modal intelektual sebagai sumber keunggulan bersaing program studi}

Berger (2008) bahwa faktor yang paling berkontribusi dalam penciptaan dan pemeliharaan keunggulan organisasi adalah sumber daya manusia. Selain itu untuk meningkatkan keunggulan bersaing tidak terlepas dari upaya-upaya meningkatkan modal intelektual melalui pendayagunaan yang optimal terhadap modal manusia, modal struktur serta modal relasinya

Juga dikatakan oleh Smedlud and Poyhonen (2005) dalam Rupidara (2008) bahwa intellectual capital a significant source of competitiveness, baik pada level organisasi maupun nasional.Begitupula dalam pembahasan ini untuk lebih jelasnya, bahwa modal inelektual sebagai sumber keunggulan program studi akan diuji melalui uji sbb:

Hipotesis Uji:

$\mathrm{H}_{0}: \gamma_{11}=0 \quad$ Tidak terdapat pengaruh dari variabel modal intelektual terhadap keunggulan bersaing program studi

$\mathrm{H}_{1}: \gamma_{11} \neq 0 \quad$ Terdapat pengaruh dari variabel modal intelektual terhadap keunggulan bersaing program studi

Untuk menguji hipotesis di atas digunakan statistic uji t student sebagai berikut:

$$
t_{i}=\frac{\hat{\gamma}_{1 i}}{\operatorname{se}\left(\hat{\gamma}_{1 i}\right)} ; \mathrm{i}=1,2
$$

Dengan $\hat{\gamma}_{1 i}$ taksiran dari koefisien pengaruh variabel laten eksogen terhadap endogen, dan se $\left(\hat{\gamma}_{1 i}\right)$ nilai standar error penaksiran parameter model yang diperoleh melalui proses resampling atau bootstrap. Melalui program Visual PLS diperoleh nilai t hitung sebagai berikut:

Tabel 4. Rangkuman pengujian hipotesis sub model pertama

\begin{tabular}{lccccccc}
\hline & Pengaruh & $\begin{array}{c}\text { Koefisein } \\
\text { Pengaruh }\end{array}$ & $\mathbf{R}^{2}$ & $\begin{array}{c}\text { Standar } \\
\text { Error }\end{array}$ & $\begin{array}{c}\text { Nilai t } \\
\text { hitung }\end{array}$ & $\begin{array}{c}\text { Nilai } \\
\mathbf{t} \\
\text { tabel }\end{array}$ \\
\hline $\begin{array}{l}\text { Modal } \\
\left(\xi_{1}\right)\end{array}$ & Intelektual & $\rightarrow \quad \begin{array}{l}\text { Keunggulan } \\
\text { Bersaing }\left(\eta_{1}\right)\end{array}$ & 0.31 & 0.10 & 0.06 & 5.10 & 2.01 \\
\hline & & & & & & & \\
$\mathrm{R}^{2}$ & $=0.314$ & & & & & \\
$\mathrm{~F}_{1}$ & $=11.900$ & & & & & \\
Ftabel & $=3.17$ & & &
\end{tabular}

Sumber: Hasil Penelitian 2011

Dari hasil perhitungan yang terangkum dalam Tabel 4 di atas diperoleh informasi, nilai t hitung untuk pengaruh variabel modal intelektual terhadap keunggulan besaing sebesar 5.10 sedangkan nilai tabel t-student sebesar 2.01. Kriteria pengujian hipotesis adalah tolak hipotesis nol yang menyatakan tidak ada pengaruh dari variabel modal intelektual tehrhadap keunggulan bersaing program studi jika nilai $t$ hitung lebih besar dibandingkan dengan nilai $t$ tabel pada tingkat signifikansi $5 \%$ dan derajat bebas $\mathrm{df}=52$ yaitu sebear 2.01. Hasil perhitungan menunjukkan variabel eksogen memiilki nilai t hitung yang lebih besar daripada nilai t tabel sehingga dapat disimpulkan terdapat pengaruh dari variabel modal intelektual terhadap keunggulan bersaing program studi. 
Dengan kata lain semakin baik modal intelektual maka akan berdampak positif terhadap semakin meningkatnya keunggulan bersaing program studi. Jika dilihat dari nilai $\mathrm{R}^{2}$ untuk variabel dapat dijelaskan bahwa sebesar 10\% perubahan dari keunggulan bersaing semata-semata dipengaruhi oleh perubahan pada variabel modal intelektual.Untuk bisa mengkategorikan apakah pengaruh ini termasuk pengaruh yang lemah, sedang ataukah kuat, dapat dilakukan kategorisasi berdasarkan nilai effect sized $\mathrm{f}^{2}$. Jika nilai $\mathrm{f}^{2}$ mendekati 0.02 maka pengaruhnya lemah, jika mendekati 0.15 maka dinyatakan pengaruhnya medium, dan jika mendekati 0.35 maka dinyatakan pengaruhnya besar (Henseler, 2009). Hasil perhitungan dengan menggunakan program XLSTAT 2011, diperoeh effect sized $\mathrm{f}^{2}$ untuk variabel modal intelektual terhadap keunggulan bersaing sebesar 0.106 lebih dekat kepada nilai 0.15 sehingga dapat dinyatakan pengaruh modal intelektual terhadap keungggulan bersaing program studi dalam kategori medium.

Hasil ini menjelaskan bahwa modal intelektual merupakan faktor penting dalam upaya meningkatkan keunggulan bersaing program studi. Melalui upaya yang serius dalam memperbaiki kemampuan intelektual civitas akademis maka dapat dipastikan akan ada peningkatan keunggulan bersaing program studi. Seperti analisis modal intelektual yang diungkapkan oleh baik Shultz dalam Marimutu 2009 maupun pendapat Lisa Boldt at all (2007), mengatakan bahwa modal intelektual merupakan modal yang tidak terlihat secara nyata, namun memberikan nilai tambah yang sangat besar bagi stakeholders dan memberikan keunggulan kompetitif. Dalam kajian ini artinya bahwa program studi harus memiliki pimpinan, dosen dan tenaga administrasi yang unggul. Hal ini dapat dicapai, apabila ketua program studi mendayagunaan modal manusia secara optimal, melalui pelatihan dan pendidikan.

\section{KESIMPULAN DAN SARAN}

\section{Kesimpulan}

Berdasarkan pemaparan di atas maka dapat disimpulkan sebagai berikut:

1. Secara umum seluruh program studi sarjana Perguruan Tinggi Negeri di Bandung telah mendayagunakan modal intelektual secara optimal, dengan meningkatkan kemampuan ,keterampilan, sikap dan perilaku sumber daya manusia (modal manusia) melalui proses pelatihan, pendidikan dan pengembangan serta menggunakan, system, prosedur dan infrasturktur (modal structural) yang tersedia. Sedangkan yang kurang didayagunakan adalah modal relasi berupa patisipasi, keangotaan serta kolaborasi/kerjasama dengan instansi lain dalam program pengajaran, penelitian dan pengabdian pada masyarakat.

2. Tingkat pencapaian keunggulan bersaing program studi sarjana Perguruan Tinggi Negeri di Bandung sudah unggul. Aspek yang paling penting dalam menentukan keunggulan bersaing adalah dimensi non-subtitutable dan rare yaitu sumber daya manusia (pimpinan, dosen,dan tenaga administrasi ) yang memiliki tingkat pengendalian diri,empati dan bakat yang tinggi dalam melayani mahasiswa, memiliki kompetensi yang langka ditemukan dalam menjalankan tugasnya. Sedangkan yang, masih kurang unggul adalah dimensi valuable dan inimitate, yaitu sumber daya manusia, khususnya tenaga administrasi yang belum sepenuhnya menjalankan tugas dengan cara yang efektif serta belum menunjukkan kreatifitasnya dalam melayani mahasiswa.

3. Pada program studi sarjana Perguruan Tinggi Negeri di Bandung, ditemukan, terdapat pengaruh modal intelektual terhadap keunggulan bersaing. Hal ini ditunjukkan dengan pendayagunaan 
modal intelektual secara optimal maka pimpinan, dosen dan tenaga administrasi yang unggul tercapai. Dengan kata lain bahwa modal intelektual sebagai sumber untuk tercapainya keunggulan bersaing pada program studi

\section{Saran}

1. Pimpinan program studi harus mendukung pada dosennya untuk ikut dalam keanggotaan berbagai instansi sesuai dengan bidang ilmunya, sehingga diharapkan akan ada kerjasama yang baik dan saling memberi informasi dalam berbagai hal yang berkaitan dengan perkembangan program studi. Program studi juga harus menjadi anggota perkumpulan ilmu pengetahuan yang ada di dunia, serta lebih aktif dalam melakukan kerjasama dengan instansi lain dalam bidang pengabdian /pelayanan pada masyarakat, karena hal ini dapat meningkatkan diri, memotivasi para dosen sebagai sumber daya manusia atau asset program studi

2. Memfokuskan peningkatan pada sumber daya manusia melalui dukungan terhadap pendidikan, pelatihan dan pengembangannya, sehingga menjadi unggul yang memiliki nilai, langka, tidak dapat ditiru dan tidak tergantikan, yang akan menghasilkan hak paten.

\section{REFERENSI}

Ai-Hwa Quek, (2005), "Learning for the Workplace: A Case Study in Gaduate Employees "Generic Competencies, Journal of Workplace Learning, Vol, 17 No 4. 2005, pp 231-242.

A.M.LilikAgung (2007); "Human Capital Competencies “, PT Edex Media Komputindo Jakarta.

Atul Gupta \&Jason McDaniel (2000), “Creating Competitive Advantage By Effectively Managing Knowledge: A Framwork for Knowledge Management, Journal of Knowledge Management Practice.

Bontis N. eds. (2003) the Strategic Management of Intellectual Capital \&Organisational Knowledge. New York: Oxford University Press, Inc. 621-642.

Brinker, Barry (2000), “Intellectual Capital: Tomorrows Asset, Today’s Challenge”,

Boudreau, John W. and Peter M. Ramstad (2007). Beyond HR: The New Science of Human Capital. Boston: Harvard Business School Press.

Bauer Roy, Tang Victor, (1995) "Competitive Dominance, Beyond Strategic Advantage and Total Quality Mangement “. Van Nostrand Reinhold

Dikti. (2003), Direktorat Jenderal PendidikanTinggi, Depdiknas, 1996. Kerangka Pengembangan Pendidikan Tinggi JangkaPanjang 2003-2010.Dokumen di http://www.dikti.go.id/Archive 2007/KPPTJP. 2003-2010 .pdfdiverifikasi aktif pada tanggal 28 Juni 2009.

EdvinsonL (2000) "Some Perspective on Intagible and Intellectual Capital, journal of Intellectual capital vol 1.no 3, pp12-23

Esposito Vinziet all (Eds) (2010), Handbook of Partial Least Square. Springer Handbook of Computational Statistics, DOI 10/1007/978-3-540-32827-8 3/Springer-Verlag Berlin Heidelberg.

Ramirez, Yolanda (2007), Intellectual Capital Management in Spanish Universities, journal of Intellectual capital vol 8 no 4, pp 732-748

Sanchez, M, Paloma and Susana Elena, (2006), Intellectual Capital in Universities, Journal of Intellectual Capital, Vol 7, No4, 2006, pp, 529-548. 
MODAL INTELEKTUAL SEBAGAI SUMBER

KEUNGGULAN BERSAING BERBASIS NILAI (CARBV)

Joeliaty

(STUDI PADA PROGRAM STUDI PERGURUAN TINGGI

NEGERI DI BANDUNG JAWA BARAT)

Sanchez, M, Paloma and Susana Elena, (2006), Intellectual Capital in Universities, Journal of Intellectual Capital, Vol 7, No4, 2006, pp, 529-548. 